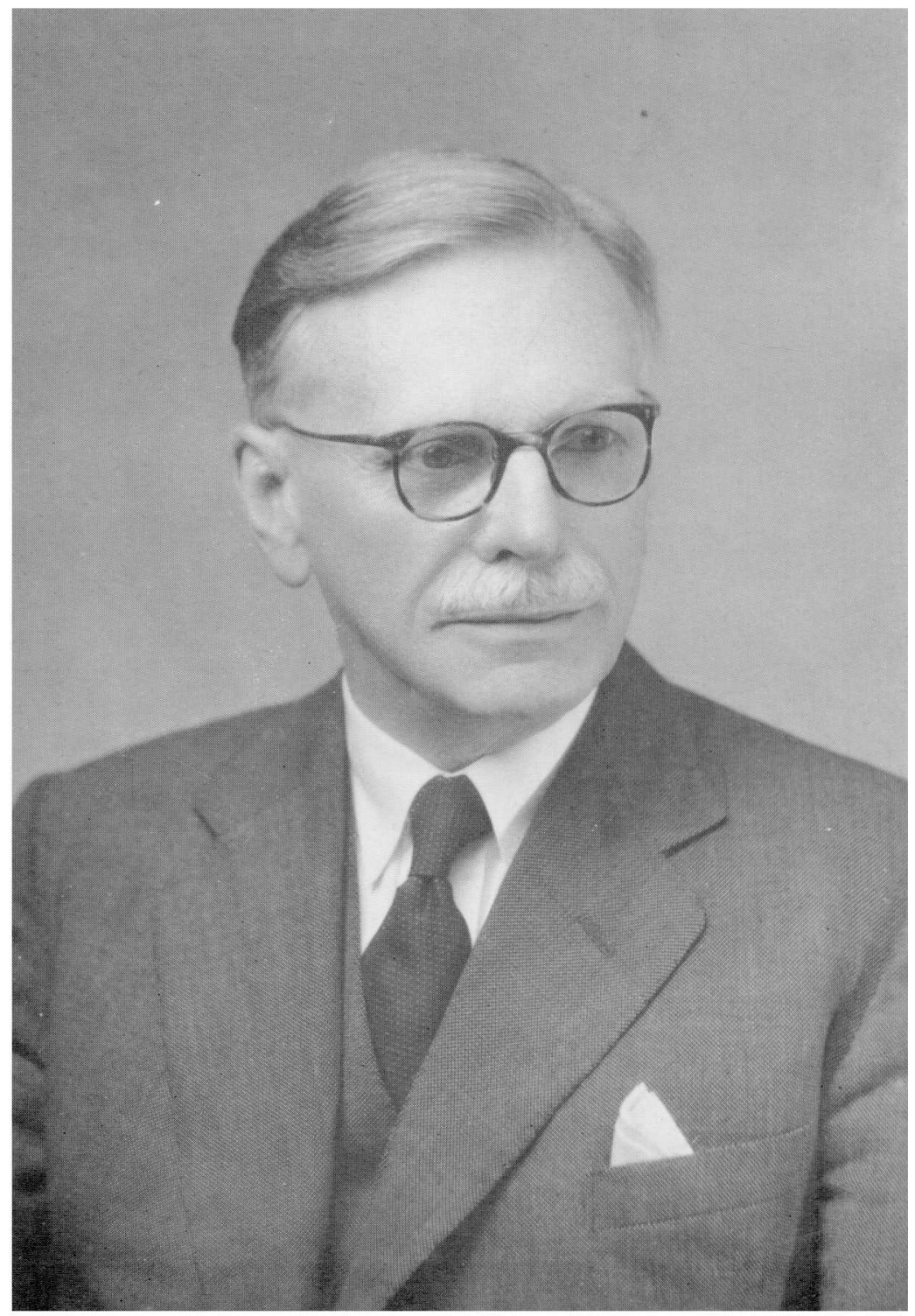

\title{
JoHN Rupert FirTH
}

BSOAS. XXIV] 


\section{OBITUARY}

\section{JOHN RUPERT FIRTH}

After a long illness in 1959, when he spent many weeks in hospital, Firth was compelled to husband his strength, but his mental agility and his enthusiasm for the things that interested him were undiminished, and on the day of his sudden death, 14 December 1960, he was to have come to London for a threeday conference called by the British Council to consider the teaching of English as a second language. It was surely the kind of end one would have wished for him.

Born on 17 June 1890, Firth read history at the University of Leeds, and after graduating with first class honours in 1911 took his M.A. degree in 1913. In this year, after a short period as a lecturer in history at the City of Leeds Training College, about which he seldom spoke, and which he probably did not enjoy, he joined the Indian Education Service, and was from 1920 to 1928 Professor of English in the University of the Punjab in Lahore, where his legend, we are told, still lives. Of this period, as of his war service in Africa, he would speak with relish, but he was eager in the end to come home, and always referred with gratitude to Professor Daniel Jones for his appointment in 1928 as senior lecturer in the Department of Phonetics at University College, London. He remained on Professor Jones's staff until 1938, holding meanwhile a number of part-time appointments elsewhere: as assistant in the sociology of languages at the London School of Economics, where he worked with Malinowski; as special lecturer in the phonetics of Indian languages at the Indian Institute, Oxford ; and as part-time lecturer in linguisties at the School of Oriental Studies, as it then was called. In 1937, he was awarded a Leverhulme Fellowship, and spent the next fifteen months in India, working mainly on Gujarati and Telugu.

Though his connexion with the School dates from 1932, it was in 1938, on his return from India, that he first became a full member of its society with his appointment as a senior lecturer. The title of Reader in Linguistics and Indian Phonetics was conferred on him by the University in 1940, and in 1941 he succeeded Professor Lloyd James as head of the Department of Phonetics and Linguistics. In 1944, when the University established a chair of general linguistics, the first in this country, he became its first occupant.

When he took over the headship of the department, there was in addition to himself one lecturer in phonetics, and he took pride in the fact that when he retired in 1956, his tenure having been extended beyond what was then the normal age of retirement, he had a permanent staff of twelve. It was, moreover, a matter of great satisfaction to him that he had been responsible for the training of nine young lecturers in the School who had been appointed to his department before their ultimate transfer to others.

During the Second World War, he was quick to see how his theory of 
'restricted languages' and the application of phonetic techniques could be turned to practical use in the training of Service personnel for intelligence work, and a large number of young men in the Armed Forces were, after much hesitation on the part of the authorities, sent to his department for short intensive courses. These proved very successful, and were continued until the end of the war, though he also provided longer courses for other purposes. His services in this respect were publicly recognized by the award of the O.B.E. in 1946.

Firth often described himself as a traditionalist in his way. Though he strove with success for the recognition in this country of modern linguistics as an academic discipline in its own right, such names as Pānini, Alfric, Bell, and Sweet were constantly on his lips. In spite of his own very original outlook, he felt that he was one in the long line of those who have contributed to the understanding of language, and he was able to communicate this sense of continuity to his pupils. He had planned to give a full account of his theory in a book to be entitled Principles of linguistics, but this never appeared in his lifetime, and it remains to be seen whether he has left material in a form sufficiently organized for publication. In Papers in linguistics, published in 1957, are collected those of his articles written between 1934 and 1951 that he considered to have most importance, and, also in 1957, he contributed to Studies in linguistic analysis, published by the Philological Society, 'A synopsis of linguistic theory, 1930-1955', in which he outlined his own position. His writings are suggestive and stimulating, but, partly because of his own kind of rhetoric, not always easy to follow for those who have not been associated with him, and they seldom show any of his many fertile ideas worked out in detail. His influence, which was undoubtedly very great, was mainly exercised in direct contact with colleagues and students, numbers of whom are now teaching in various parts of the world. His Wednesday morning lectures were something of a university institution, and were attended by many students and members of staff from other London colleges.

There was profit in listening to Firth on any linguistic topic, including the application of his techniques to the study of literary texts, to which he gave increasing attention, but his name is especially associated with his theory of meaning as a complex of contextual relations, and, in phonology, with prosodic analysis. He took over and developed Malinowski's notion of context of situation, regarding this as a construct in which an attested linguistic 'text' was one element among other relevant social and environmental items. As he understood it, the object of linguistic analysis was 'to make statements of meaning so that we may see how we use the language to live ', 1 and this involved analysis at a number of different levels, situational, collocational, syntactical, phonological, and phonetic, each of which contributed to the 'meaning', the word being thus given an unusually great extension. It can be observed

1 Studies in linguistic analysis, Oxford, 1957, 23. 
that the word 'levels' is increasingly used with something of the sense he gave to it, though not always with what he saw as its full implications.

His theory of prosodic analysis is characterized by its concern with features affecting more than minimal stretches of speech and by its 'polysystemic' approach: it does not seek to establish phonological units valid for the language as a whole, but sets up as many systems as are found necessary for relating the phonic data with the grammatical and other features of the language. There are signs of growing awareness of the need for such an approach if an adequate linguistic statement is to be achieved.

Firth at all times insisted on the need for authentic texts. He was impatient of the artificial examples that are unfortunately apt to mar linguistic works, and, in the tradition of Sweet, for whom he so often expressed admiration, he demanded sound phonetics as the basis of everything else. Respect for the material dominated Firth's attitude. He maintained that it was impossible to do fruitful work in linguistics without a theory, but he distinguished a general theory for particular application from a theory of universals for general application, and he saw danger for the subject in preoccupation with methodology and procedural rules.

In 1947, Firth spent three months as visiting professor in the Faculty of Arts of what was then the Farouk I University in Alexandria, and in 1948 he joined the staff of the Linguistic Institute of America at the University of Michigan, Ann Arbor, for its summer session. He also visited and gave lectures in a number of European universities. In 1951, he took part in the colloquium on semantics held in Nice under the auspices of the Société Linguistique de Paris, and he later attended meetings of the UNESCO Commission for Language Research. In this country, he was a member of the Linguistic Committee of the Colonial Social Science Research Council and of the Linguistic Panel of the English Studies Advisory Committee of the British Council.

Firth had given much attention to the problem of providing a roman script for Indian languages, and he had taken a keen interest in braille for India. The subcontinent was always dear to him, and in 1957, after his retirement, he accepted with alacrity an invitation from the British Council to spend some months in Pakistan as adviser on linguistic matters. During his stay he visited a large number of science departments and technical colleges, and reported to the Government of Pakistan on the teaching of English for the purposes of science and technology. He also took part in the Language-Teaching Conference called by the Ministry of Education in Karachi, as well as in many informal discussions, which he greatly enjoyed.

Retirement had no allurement for him, and he was delighted to spend two terms in 1958 as a visiting lecturer in the Eniversity of Edinburgh. He was attached to the Department of English Language and General Linguistics, but his work lay almost entirely in the recently founded School of Applied Linguistics, where he lectured and conducted seminars and put his long and 
varied experience at the disposal of the Director and staff. It was a happy time for him, and when he returned to the south he displayed with gleeful pride the card that showed him to be a full member of the Students' Union. In July of last year, the University, to his great pleasure, conferred on him the honorary degree of LL.D.

The Philological Society, of which he was a member from 1933, had a very important place in Firth's life. He attended its meetings whenever he could, and invariably took an active part in the discussions. From 1934, he was a member of its Council, and he served for a time as secretary for publications. It is probably no exaggeration to say that his election as President in 1954 gave him as much satisfaction as any other event in his career. He held the office for three years, and was a Vice-President from 1959 to the time of his death. Though he was not able to attend meetings in later days, he never lost his interest in the Society's affairs, and he frequently corresponded with the secretary about them.

It was not only as a scholar and teacher that Firth served the University and the School. What he achieved as chairman of the School's Publications Committee has been related by Sir Ralph Turner in the volume of the Bulletin that was issued in his honour. ${ }^{1} \mathrm{He}$ was a most valuable, if at times an exasperating, member of a committee-for it is hard to believe, in spite of his disclaimers, that he did not dearly love a fight. On boards of studies and all the most important committees of the School, he displayed his grasp of business, and he never allowed anything to go by default. He was not always right; but, if one found oneself in opposition to him, it was worth while to examine one's case again, for his hunches had a way of being justified by the event. He would say 'My loyalty is to my subject', but in fact no one worked harder than he for the common good, or was more influential in the shaping of policy. He took a great deal of interest in the University's summer vacation course in English for foreign students, and was for some years chairman of the advisory committee concerned with this. To this work, as to everything he touched, he brought a fierce concentration and a passionate concern for detail.

Though Firth was very proud of his Yorkshire origin, his excitable temperament was not of a kind that is conventionally associated with Yorkshiremen. He took a certain satisfaction in his emotional extravagance, and saw little virtue in controlling it. He would pass in a moment from the depths of gloom to a mood of boisterous gaiety, and in the midst of the violent denunciation of some evil-doer, real or imaginary, he could be moved to delighted laughter by a remark that appealed to his sense of humour. Rather abnormally sensitive to criticism, and firmly believing in the merit of getting his blow in first, he was not an easy person to deal with. He could, indeed, be almost unforgivably offensive; yet such was the charm of his sunnier moments that he commonly was forgiven. His friends had a good deal to contend with, but they found it

1 BSOAS, xviII, 3, 1956. 
worth while and were many, though it is true to say that he was in some ways a lonely man.

He would talk with anyone he met, and could arouse an interested-and, as often as not, an interesting-response. In a group, he was, like all the great conversationalists, apt to run to monologue; but at his best he was superb, and could bring before his hearers the persons and places and events of his life in a way that made them feel that they had an intimate share in his own rich experience.

I find myself forgetting that for many years Firth suffered from ill health. But this is not strange ; for though we heard a great deal about his symptoms and his doctors and his diets, as we did about most things in his life, it was not really possible to think of him as a sick man. The abundant outpouring of energy went on through everything, and it is hard to imagine that he could have been more fully alive.

N. C. SCOTT

\section{PROFESSOR J. R. FIRTH-BIBLIOGRAPHY ${ }^{1}$}

'Pioneers', being selected prose for language study. Compiled and edited with notes, glossary and exercises by J. R. Firth and M. G. Singh. London : Macmillan and Co., Ltd., 1929. ix, 259 pp.

Speech. (Benn's Sixpenny Library, No. 121.) London : Ernest Benn Ltd., 1930. 80 pp.

Notes on the transcription of Burmese. BSOS, VII, 1, 1933, 137-40.

Linguistics and the functional point of view. English Studies, XvI, 1, 1934, 2-8.

*The principles of phonetic notation in descriptive grammar. In Congrès International des Sciences Anthropologiques et Ethnologiques. Compte-rendu de la première session, Londres, 1934. Londres: Institut Royal d'Anthropologie, 1934, 325-8. [Items preeeded by an asterisk were reprinted in Papers in linguistics, 1934-1951.]

Sectional proceedings of the International Congress [of Anthropological and Ethnological Sciences, first session, London, 1934]. Section H. Languages and writing. Man, xxxIv, Sept. 1934, No. 174, pp. 150-2.

A short outline of Tamil pronunciation. In A. H. Arden : A progressive grammar of common Tanil. Fourth edition, revised throughout by A. C. Clayton. (Tamil Study Series, No. 2.) [Madras] : Christian Literature Society for India for the Church Missionary Society, 1934, Appendix, xxxiv pp.

*The word 'phoneme'. Maître Phonétique, Troisième Série, No. 46, 1934, 44-6.

*'The technique of semantics. TPS, 1935, 36-72.

*The use and distribution of certain English sounds : phoneties from a functional point of view. English Studies, xvil, 1, 1935, 2-12.

*Alphabets and phonology in India and Burma. BSOS, vur, 2-3, 1936, 517-46.

*Phonological features of some Indian languages. In Proceedings of the second International Congress of Phonetic Sciences, held at University College, London, 22-26 July 1935. Cambridge: University Press, 1936, 176-82.

*The structure of the Chinese monosyllable in a Hunanese dialect (Changsha). [With B. B. Rogers.] BSOS, vIII, 4, 1937, 1055-74.

The tongues of men. London : Watts \& Co., 1937. vii, $160 \mathrm{pp}$.

A practical seript for India. Indian Listener, III, 6, 1938, 356-7.

Specimen : Kashmiri. Maître Phonétique, Troisième Série, No. 68, 1939, 67-8.

1 This bibliography, which excludes only reviews (of which Firth wrote very few) and small notes, is believed to be complete at the time of going to press. The compiler wishes to express his sincere thanks to Miss D. M. Johnson and Miss Jean M. Wheeler for the assistance they have given him in this work. 
Speech in fellowship and community. The New Era in Home and School, xxI1, 8, 1941, $185-9$. [Alphabets for Indian languages.] In Daniel Jones : The problem of a national script for India. Lucknow : Pioneer Press; Hertford: Stephen Austin \& Sons, 1942, 12-17.

Introduction [on pronunciation and the alphabet]. In A. H. Harley : Colloquial Hindustani. London : Kegan Paul, Trench, Trubner \& Co. Ltd, 1944, ix-xxx.

Wartime experiences in linguistic training. Modern Languages : a journal of modern studies, xxvi, 2, 1945, 38-46.

*The English school of phonetics. TPS, 1946, 92-132.

The place of the spoken language and the use of technical aids in language teaching. In Proceedings of the Sir William Jones Bicentenary Conference held at University College, Oxford. September 2-6, 1946. London : Royal India Society, [1947], 30-3, 59.

*'The semantics of linguistic science. Lingua, r, 4, 1948, 393-404.

*Sounds and prosodies. TPS, 1948, 127-52.

*Word-palatograms and articulation. BSOAS, xII, 3-4, 1948, 857-64.

*Atlantic linguistics. Archivum Linguisticum, I, 2, 1949, 95-116.

*Improved techniques in palatography and kymography. [With H. J. F. Adam.] BSOAS, XIII, 3, 1950, 771-4.

Introduction [on spelling and pronunciation]. In T. Grahame Bailey : Teach yourself Hindustani. Edited by J. R. Firth and A. H. Harley. (The Teach Yourself Books.) London : English Universities Press Ltd., 1950, xi-xli.

*Personality and language in society. Sociological Revicu, xLII, 2, 1950, 37-52.

*General linguistics and descriptive grammar. TPS, 1951, 69-87.

*Modes of meaning. Essays and Studies of the English Association, N.S., Iv, 1951, $118-49$.

Joseph Wright the scholar. Transactions of the Yorkshire Dialect Society, Ix, 55, 1955, 22-33.

Structural linguistics. TPS, 1955, 83-103.

Indian languages. In Encyclopaedia Britannica, 1956.

Introduction [on spelling and pronunciation]. In $\mathbf{T}$. Grahame Bailey : Teach yourself Urdu. Ediied by J.R. Firth and A. H. Harley. [Revised edition of Teach yourself Hindustani.] (The Teach Yourself Books.) London : English Universities Press Ltd., 1956, xi-xxxix.

Linguistic analysis and translation. In Morris Halle and others (comp.) : For Roman Jakobson : essays on the occasion of his sixtieth birthday, 11 October 1956, compiled by Morris Halle, Horace G. Lunt, Hugh McLean, Cornelis H. van Schooneveld. The Hague : Mouton \& Co., $1956,133-9$.

Philology in the Philological Society. TPS, 1956, $1-25$.

Plenary session 1. Linguistics and the problem of meaning. Report.-Preliminary remarks on the report.-Comment at the end of the first meeting.-Concluding remarks at the end of the second meeting. In Proceedings of the seventh International Congress of Linguists, London, 1-6 September 1952. London: The rith International Congress of Linguists, $1956,6-9,181-5,202,230-3$.

Applications of general linguistics. TPS, 1957, 1-14.

Ethnographic analysis and language with reference to Malinowski's views. In Raymond Firth (ed.): Man and culture: an evaluation of the work of Bronislaw Malinouski. London : Routledge \& Kegan Paul, 1957, 93-118.

Hindustani language. In Encyclopaedia Britannica, 1957.

Papers in linguistics, 1934-1951. London, etc. : Oxford University Press, 1957. xii, 233 pp.

Phonetic observations on Gujarati. BSOAS, xx, 1957, 231-41.

A synopsis of linguistic theory, 1930-1955. In Studies in linguistic analysis. Special volume of the Philological Society. Oxford: Basil Blackwell, 1957, 1-32.

'The treatment of language in general Jinguistics. Medical Press, ccxli, 8, 1959, 146-7.

R. H. ROBINS 